\title{
Relationship of Roadside Worker's Characteristic with Blood Lead Level
}

\author{
Wirsal Hasan ${ }^{1}$, Rahim Matondang ${ }^{2}$, Alvi Syahrin ${ }^{3}$, Chatarina Umbul Wahyuni ${ }^{4}$, Taufik Ashar ${ }^{5}$ \\ ${ }^{1}$ Department of Environmental Health, School of Public Health, University of Sumatera Utara, Indonesia \\ wirsal_hasan@yahoo.com \\ ${ }^{2}$ Department of Civil Engineering, School of Technology, University of Sumatera Utara, Indonesia \\ wirsalh@gmail.com \\ ${ }^{3}$ Faculty of Law, University of Sumatera Utara, Indonesia \\ wirsalhegmail.com \\ ${ }^{4}$ Department of Epidemiology, School of Public Health, Erlangga Univesity, Indonesia \\ chatrin03@yahoo.com \\ ${ }^{5}$ Department of Environmental Health, School of Public Health,University of Sumatera Utara, Indonesia \\ doctta@gmail.com
}

\begin{abstract}
Lead can insert into the body through the human digestive tract with food and drinks as well as through the respiratory tract into the lungs and blood vessels. Paddle rickshaw puller, motorized rickshaw pullers, traffic control officers, hawkers and street vendors located in major cities in Indonesia are the most exposed workers to lead from the airpollution produced by motor vehicles. Lead pollution which they faceover the years working in the roadside is a serious threat to their health permanently.

This is a descriptive analytic study by examining the characteristics of roadside workers for lead poisoning and analyze the characteristics of the respondent's relationship with blood lead levels. The sample in this study is the paddle rickshaw puller, motorized rickshaw pullers and street vendors located alongside a road.

The results with the Man Whitney tests howed that there are differences in the mean blood lead levels were significantly according to gender $(p=0.047)$ and smoking habits $(p=0.03)$, but there is no difference in mean blood lead levels based on the type of work, long of work, education level, place of rest, location of residence, drinking milk, and alcohol drinking habits.

The analysis using Pearson correlation test and Spearman correlation found no significant correlation between the variables age, systolic blood pressure and diastolic blood pressure on blood lead levels $(p>0,05)$. The final resul sobtained by multivariate modelling of independent variables that have a significant effect on the levels of lead in the blood is the diastolicb loodpressure and sex. $R 2$ value (coefficient of determination) final model is 0:12, it was concluded that the diastolic blood pressure variables and sex were able to predict blood lead levels by $12 \%$, while the rest $(100 \%-12 \%) 88 \%$ is explained by other factors that not examined.
\end{abstract}

Keywords - age, blood pressure, type of work, long of work, education level, place of rest, smoking habits, blood lead level

\section{INTRODUCTION}

Lead $(\mathrm{Pb})$ was originally a heavy metal that is naturally present in the earth's crust. Lead polluting the air, water and soil. This pollution can come from natural sources and human activity so that number continues to increase. Lead is a metal that should get attention because they are highly toxic to humans. Lead can enter into the body through the human digestive tract, such as food and beverages, and as dust in the respiratory tract breathing air contaminated with lead. Lead intoxication can occur through oral, through food, beverages, breathing, through the skin contact, through eye contact, as well as through parenteral.

Lead is used in the battery industry, cable, gilding, pestisida, as a substance antiknock on gasoline, solder or solder materials, as formula tions pipe fitting and others. consumption for transportation in 1999 amounted to 11,515,401 kiloliters. Premium lead containing $0.45 \mathrm{~g} / \mathrm{L}$ so that the amount of lead released into the air amounted to 5,181,930 tons. With car sales growth of $300 \%$ and a motorcycle at $50 \%$, is expected in $2001 \mathrm{~Pb}$ pollution increased to 1.7 to $5 \mu \mathrm{g} / \mathrm{m} 3$ [1].

Research by Kozak in 1993 stated that air pollution, especially lead emissions in 1991 amounted to $733,154.42$ tons from $98.61 \%$ of the transport and industry; $1.39 \%$ of the households, and the amount of waste elimination is very low. Premium gasoline 87 octane and super gasoline with an octane rating of 98 containing 0.70 to 0.84 tetraethyl and tetramethyl- $\mathrm{Pb}$, thus amounting to 0.56 to $0.63 \mathrm{~g}$ of lead discharged into the air in every liter of petrol. 
The main sources of lead pollution comes from motor vehicle exhaust emissions which occupies $90 \%$ of lead emissions in the atmosphere.

Research shows that the content of lead in the air of dense urban traffic amounted to 0.1-0.2 ppm and the content of lead in the blood of nearby residents is more than $0.3 \mathrm{ppm}$. Based on research that traffic levels affect the levels of blood lead vendors. On the Yos Sudarso street, in Surakarta, with heavy traffic showed lead levels in the air of 0.0007 to $0.021 \mathrm{mg} /$ cubic $\mathrm{m}$ and lead levels in blood hawkers of 0.366 to $0.806 \mathrm{ppm}$. On the Supratman street, with moderate traffic density showed lead levels in the air of 0.005 to $0.015 \mathrm{mg} / \mathrm{m} 3$ and blood lead levels hawkers of 0.124 to $0.339 \mathrm{ppm}$. At the Veteran street, in Surakarta, with low traffic density, ie 2055-2490 vehicles / hour which showed levels of lead in the air of 0.0048 to $0.0096 \mathrm{mg} / \mathrm{m} 3$ and blood lead concentrations in street vendors for 0176-0298 ppm [1].

Lead contaminants in urban air is mainly formed of a fuel gas containing organic lead (TEL = tetra ethyl lead) are released into the air, to further contaminants transferred to the ambient air through the community, which ultimately disrupted by members of the public due to these contaminants, especially those at high risk. Lead is a systemic poison which can cause lead poisoning encephalophathy. On acute poisoning symptoms will occur and cerebral meninges, followed by stupor, coma, Liquor cerebrospinalis (LCS) pressure is high, insomnia and somnolence [2]

There are several characteristics that can be used to determine whether a risk to contain high levels of lead in the blood include: where to stay in town or in the villages, homes that contain lead paint, unhealthy housing conditions, shelter in place that densely populated, low education level and others [3]

Wahyudiono doing research in Surabaya on blood lead levels in traffic policemen wear a mask while on duty than the police who did not wear masks. Of 24 police officers on duty at a traffic congested, gained the lead content in the blood of $31.6 \mu \mathrm{g} / 100$ $\mathrm{ml}$, while that who does not wear a mask with an average of $49.2 \mu \mathrm{g} / 100 \mathrm{ml}$ of blood [4]

Gravitiani research showed in 2008 in Yogyakarta there were 29,234 cases of decreased IQ in children as the health effects caused by lead. In addition there are also as many as 3,732 cases of hypertension, 4 cases of coronary heart disease, and 4 cases of premature death. Children are the group most vulnerable to lead. The higher the lead content in the blood, the lower the child's level of intelligence [5]

Vupputuri et all examined the relation between blood lead levels and blood pressure in a representative sample of 14952 whites and blacks aged 18 years or older who participated in the Third National Health and Nutrition Examination Survey. Blood lead was measured by atomic absorption spectrophotometry and blood pressure by standard sphygmomanometryMean blood lead levels were significantly higher for black men and women (5.4 and $3.4 \mathrm{~g} / \mathrm{dL}$, respectively) compared with white men and women (4.4 and $3.0 \mathrm{~g} / \mathrm{dL}$, respectively). After multivariate adjustment for important covariables, each standard deviation higher blood lead $\left(3.3 \_\mathrm{g} / \mathrm{dL}\right)$ was associated with a $0.82(95 \%$ confidence interval [CI], 0.19 to 1.44$) \mathrm{mm} \mathrm{Hg}$ and a 1.55 (95\% CI, 0.47 to 2.64) $\mathrm{mm} \mathrm{Hg}$ higher systolic blood pressure among black men and women, respectively. In contrast, blood lead level was not associated with blood pressure among white men or women [6]

Nawrot and Staessen, in view of the Menke et al report and our observations in adolescents, 3 blood lead concentrations as low as 0.10_mol/L likely represent a public health hazard. In NHANES 1999 to $2000,538 \%$ of US adults had a blood lead level above this threshold. This proportion is likely to be higher among the less privileged in industrialized countries and among citizens of developing countries, where environmental regulations are either less stringent, nonexistent, or not applied. In areas with historical contamination of the soil by heavy metals, house dust remains a persistent source of exposure even decades after the cessation of the industrial activity. 22 People living on polluted soils remain exposed to lead via fine particulate (PM10) suspended in the air at a level 17times the normal background value (measuring station 0BE01, 576 versus $17 \mathrm{ng} / \mathrm{m} 3$ [7]

Menke et all revealed that the association between blood lead levels and increased all-cause and cardiovascular mortality was observed at 
substantially lower blood lead levels than previously reported. Despite the marked decrease in blood lead levels over the past 3 decades, environmental lead exposures remain a significant determinant of cardiovascular mortality in the general population, constituting a major public health problem [8]

The International Agency for Research on Cancer (IARC) has classified inorganic lead compounds as Group 2A carcinogens (likely to cause human cancer). The National Toxicity Programme in the USA states that lead is reasonably anticipated to be a human carcinogen based on limited human studies but sufficient animal laboratory data and the US Environmental Protection Agency states that lead is a probable human carcinogen. At very high blood lead levels, lead is a powerful abortifacient. At lower levels, it has been associated with miscarriages and low birth weight of infants. In females, occupational exposure resulting in blood lead levels $>10 \mu \mathrm{g} / 100 \mathrm{ml}$ is associated with an increased risk of spontaneous abortion, premature delivery and low birth weight. In one study, the risk of spontaneous abortion doubled at maternal blood lead levels of 5-9 $\mu \mathrm{g} / 100 \mathrm{ml}$. Recent studies have shown that blood lead levels in men $>40 \mu \mathrm{g} / 100 \mathrm{ml}$ may be linked to low libido, low semen volume and sperm counts, increased abnormal sperm morphology and decreased sperm motility leading to impairment of reproductive function [9]

Peters at all in their studied about Childhood and Adult Socioeconomic Position, Cumulative Lead Levels, and Pessimism in Later Life. Pessimism was measured by using the Life Orientation Test. Cumulative (tibia) lead was measured by x-ray fluorescence. Structural equation modeling was used to quantify the relations as mediated by childhood and adult SES (Socio Economic Status), controlling for age, health behaviors, and health status. An interquartile range increase in lead quartile was associated with a 0.37 increase in pessimism score $(\mathrm{P}<0.05)$. Low childhood and adult SES were related to higher tibia lead levels, and both were also independently associated with higher pessimism. Lead maintained an independent association with pessimism even after childhood and adult SES were considered. Results demonstrate an interrelated role of lead burden and
SES over the life course in relation to psychological functioning in older age [10]

Paddle rickshaw puller, motorized rickshaw pullers, official traffic control, street vendors located in major cities in Indonesia are high-risk workers with air pollution produced by motor vehicles. Starting from the morning, even since the rising of the sun they were out of the house, located along a busy highway, until the afternoon even up to the night, either at work or in a state of rest continuously exposed to air pollution, in this case is the lead pollution generated by motor vehicle exhaust emissions.

It is known that lead pollution they face over the years working in the street is a serious threat to their health permanently. Health problems caused by chronic lead poisoning they experienced every day is a "silent killer" for patients resulting in reduced productivity and the education and lives of his family members. In an effort to protect people who are exposed to this, it is necessary to do some research to find the characteristics that influence the levels of lead in their blood.

\section{MATERIALS AND METHODS}

This research is a descriptive analytic study by examining the characteristics of roadside workers and analyze the characteristics of the respondents relationship with blood lead levels (BLL). Samples were taken from the roadside workers who came went to one clinic in the city of Medan in consecutive sampling.

The study population was adult workers at high risk against lead pollution in the city of Medan, affordable population is adult workers high risk such as paddle rickshaw puller, motorized rickshaws puller, traffic control personnel, roadside vendors, road side workers, public bus driver in the district of East Medan, in the city of Medan. The sample was adult workers who volunteered to come to the Widya Husada Hospital.

Criteria for inclusion in this study were adults (aged over 18 years), men and women, length of the high-risk labor at least 2 years, willing to follow the study after signed Consent Form to participate in the Research.

Participant's blood was taken with the technique sterile, plus anti-blood clotting. Blood samples 
examined the levels of lead with the help of a spectrophotometer by laboratory personnel Prodia Clinic in the city of Medan in collaboration with Petrolab Services in Jakarta. Participants provide letter of consent to participate in the study (informed concent).

\section{RESULTS}

TABLE I

CHARACTERISTICSOF RESPONDENTS

\begin{tabular}{|c|c|}
\hline Characteristics of Respondents & $\mathrm{n}=\mathbf{1 0 9}$ \\
\hline Age, mean (SD) & $47.57(13.77)$ \\
\hline $\begin{array}{l}\text { Gender, } \mathrm{n}(\%) \\
\text { men } \\
\text { women }\end{array}$ & $\begin{array}{l}104(94,5) \\
5(5.5)\end{array}$ \\
\hline $\begin{array}{l}\text { Type of Work, } \mathrm{n}(\%) \\
\text { Moving } \\
\text { Not move }\end{array}$ & $\begin{array}{l}89(81.7) \\
20(18.3)\end{array}$ \\
\hline $\begin{array}{l}\text { Work duration, } \mathrm{n}(\%) \\
<5 \text { hours } \\
>5 \text { hours }\end{array}$ & $\begin{array}{l}22(20.2) \\
87(79.8)\end{array}$ \\
\hline $\begin{array}{l}\text { Smoking habits, } \mathrm{n}(\%) \\
\text { Yes } \\
\text { Not }\end{array}$ & $\begin{array}{l}76(69.7) \\
33(30.3)\end{array}$ \\
\hline $\begin{array}{l}\text { Level of education, } \mathrm{n}(\%) \\
\text { Low } \\
\text { High }\end{array}$ & $\begin{array}{l}77(70.6) \\
32(29.4)\end{array}$ \\
\hline Systolic blood pressure, the mean (SD), $\mathrm{mmHg}$ & $117.98(24.41)$ \\
\hline Diastolic blood pressure, the mean (SD), $\mathrm{mmHg}$ & $74.86(12: 37)$ \\
\hline $\begin{array}{l}\text { Resting place } \\
\text { Roadside } \\
\text { Home }\end{array}$ & $\begin{array}{l}53(48.6) \\
56(51.4)\end{array}$ \\
\hline $\begin{array}{l}\text { Location of Residence } \\
\text { Away from the roadside } \\
\text { Roadside }\end{array}$ & $\begin{array}{l}66(60.6) \\
43(39.4)\end{array}$ \\
\hline $\begin{array}{l}\text { Milk Drinking Habits } \\
\text { Yes } \\
\text { Not }\end{array}$ & $\begin{array}{l}46(42.2) \\
63(57.8)\end{array}$ \\
\hline $\begin{array}{l}\text { Alcoholics } \\
\text { Yes } \\
\text { Not }\end{array}$ & $\begin{array}{l}21(19.3) \\
88(80.7)\end{array}$ \\
\hline
\end{tabular}

TABLE II

CORRELATION OF INDIPENDENT VARIABEL ON BLOOD LEAD LEVEL

\begin{tabular}{|l|l|l|}
\hline Variable & R & P \\
\hline Age & -0.0035 & $0.719(\mathrm{a})$ \\
\hline Systolic blood Pressure & -0.177 & $0.065(\mathrm{~b})$ \\
\hline Diastolic blood pressure & 0,134 & $0,166(\mathrm{~b})$ \\
\hline
\end{tabular}

${ }^{\mathrm{a}}$ Pearson Corelation Test ${ }^{\mathrm{b}}$ Spearman Correlation Test

From the analysis using Pearson correlation test and Spearman correlation (Table 2) found no significant correlation between the variables age, systolic blood pressure and diastolic blood pressure on blood lead levels ( $p>0: 05)$.
TABLE III

THE MEAN DIFFERENCE IN BLOOD LEAD LEVELS BASE ON INDEPENDENT VARIABELS

\begin{tabular}{|l|l|l|l|}
\hline Variable & n & Mean (SD) & P \\
\hline $\begin{array}{l}\text { Sex } \\
\text { Male }\end{array}$ & 104 & $7.77(14.8)$ & 0.047 \\
Female & 5 & $13.48(6.29)$ & \\
\hline $\begin{array}{l}\text { Work duration } \\
\text { <5 hours } \\
>5 \text { hours }\end{array}$ & 22 & $7.95(5.19)$ & 0,285 \\
\hline $\begin{array}{l}\text { Job } \\
\text { Moving } \\
\text { not moving }\end{array}$ & 87 & $8.05(3.85)$ & \\
\hline $\begin{array}{l}\text { Smoking habits } \\
\text { Yes } \\
\text { No }\end{array}$ & 89 & $7.81(3.92)$ & 0.301 \\
\hline $\begin{array}{l}\text { Education } \\
\text { Low }\end{array}$ & 20 & $9.04(4.96)$ & \\
High & 76 & $7.34(3.83)$ & 0.03 \\
\hline $\begin{array}{l}\text { Resting place } \\
\text { Roadside }\end{array}$ & 33 & $9.10(4.38)$ & \\
House & 77 & $7.83(4.09)$ & 0.501 \\
\hline $\begin{array}{l}\text { Location of Residence } \\
\text { Away from the Roadside }\end{array}$ & 32 & $8.51(4.25)$ & \\
Roadside & 66 & $8,36(4.27)$ & 0.39 \\
\hline $\begin{array}{l}\text { Milk drinking habits } \\
\text { Yes } \\
\text { No }\end{array}$ & 53 & $7.58(4.02)$ & 0.146 \\
\hline $\begin{array}{l}\text { Alcoholic } \\
\text { Yes } \\
\text { No }\end{array}$ & 56 & $8.46(4.22)$ & \\
\hline
\end{tabular}

Table 3 displays the results of an analysis of differences in blood lead levels based on the independent variables are nominal scale research. Man Whitney test obtained with the differences in mean blood lead levels were significantly according to gender $(\mathrm{p}=0.047)$ and smoking habits $(\mathrm{p}=0: 03)$, but there was no difference in mean blood lead levels based on the type of work, length of work, level of education, resting place, location of residence, drinking milk and alcohol drinking habits. From the results of the bivariate analysis of independent variables that enter the model using a multivariate linear regression is variable systolic blood pressure, diastolic blood pressure, sex, smoking habits, and the rest (which has $\mathrm{p}<0.25$ ). Multivariate analysis using multiple linear regress ion with enter method are presented in Table 4.

TABLE IV

ANALISIS REGRESSION FACTORSAFFECTING LEAD LEVEL IN BLOOD

\begin{tabular}{|l|l|l|}
\hline Variabel & B & P \\
\hline Constant & 7.152 & 0.023 \\
\hline Diastolic blood pressure & -0.063 & 0.04 \\
\hline Sex & 5.386 & 0.003 \\
\hline
\end{tabular}


TABLE V

MODEL SUMMARY

\begin{tabular}{|l|l|l|l|l|}
\hline Model & $\mathbf{R}$ & $\mathbf{R}^{\mathbf{2}}$ & Adjusted $\mathbf{R}^{\mathbf{2}}$ & $\begin{array}{l}\text { Std. Error of the } \\
\text { Estimate }\end{array}$ \\
\hline 1 & $0.347(\mathrm{a})$ & 0.120 & 0.104 & 3.9105 \\
\hline
\end{tabular}

a. Predictors:(Constant), gender, diastolic blood pressure

b. Dependent Variable: Blood Lead Levels

Multivariate modeling of the final results obtained by the independent variables that have a significant effect on the levels of lead in the blood is the diastolic blood pressure and sex. In accordance with the results listed in Table 4 the

obtained equation, as follows: $\mathrm{y}=7152-00635,386$ $\mathrm{x} 1+\mathrm{x} 2$,

where $\mathrm{y}$ is the lead levels in the blood, $\mathrm{x} 1$ is the diastolic blood pressure, $\mathrm{x} 2$ is gender. $\mathrm{R} 2$ value (coefficient of determination) of the final model is $0: 12$ (table 5), it was concluded that the diastolic blood pressure variables and sex were able to predict blood lead levels by $12 \%$ while the rest $(100 \%-12 \%) 88 \%$ is explained by other factors were not examined.

\section{IV.DISCUSSION}

The results with the Man Whitney test showed that there are differences in the mean blood lead levels were significantly according to gender $(p=0.047)$ and smoking habits $(\mathrm{p}=0.03)$, but there is no difference in mean blood lead levels based on the type of work, long of work, education level, place of rest, location of residence, drinking milk, and alcohol drinking habits.

The analysis using Pearson correlation test and Spearman correlation found no significant corre lation between the variables age, systolic blood pressure and diastolic blood pressure on blood lead levels ( $p>0,05)$.

\section{CONCLUSIONS}

Analysis using Pearson correlation test and Spearman correlation found no significant correlation between the variables age, systolic blood pressure and diastolic blood pressure on blood lead levels ( $p>0: 05)$.

Man Whitney test obtained with the differences in mean blood lead levels were significantly according to gender $(p=0.047)$ and smoking habits $(p=0: 03)$, but there was no difference in mean blood lead levels based on the type of work, length of work, level of education, resting place,location of residence, drinking milk and alcohol drinking habits. Multivariate modeling of the final results obtained by the independent variables that have a significant effect on the levels of lead in the blood is the diastolic blood pressure and sex.

\section{REFERENCES}

[1] W.Widowati,.A.Sastiono,RR. Joseph,, Effects of toxic heavy metals, Yogyakarta, Andi Offset, 2008.

[2] JS. Slamet, Environmental Health, Gajah Mada University Press, Yogyakarta :117-118, 2009

[3] BP.Lanphear,R.S.Byrd, P.Aunger, and S.J.Schaffer, Community characteristics associated with elevated blood lead levels in children, Pediatrics, 101; 264-271,1998

[4] Wahyudiono and Eko Nur, (2006), The Relationship Between the Use of Masks Due to Health Effects Exposure to Pb Transport: Study of Traffic Police in the city of Surabaya, Email: library@lib.unair.ac.id

[5] E.Gravitiani, Economic Valuation Impact of Lead $(\mathrm{Pb})$ Against Motor Vehicle Exhaust Urban Public Health Yogyakarta, Dissertation, University of Gajah Mada: 67-80.2009

[6] S.Vupputuri, He Jiang, P.Muntner, L.A.Bazzano, P.K.Whelton, P. Batuman. Blood Lead Level Is Associated With Elevated Blood Pressure in Blacks, Hypertension, March 2003, 463-468.2003

[7] T.S. Nawrot, A.J.Staessen, Low-Level Environ mental Exposure to Lead Unmasked as Silent Killer, Circulation, 2006,114 13471349.2006

[8] A. Menke, P. Muntner, V. Batuman, E.K.Silbergeld, E. Guallar, Blood Lead Below $0.48 \mathrm{~mol} / \mathrm{L}\left(10 \_\mathrm{g} / \mathrm{dL}\right)$ and Mortality Among US Adults, Circulation 2006-114,1388-1394, 2006

[9] D.A. Gidlow, In-depth Review Lead Toxicity, Occupational Medicine,65. 348-356,2015

[10] J.L. Peters, L.D.Kubzansky,A. Ikeda, A. Spiro, R.O. Wright, M.G.Weisskopf, Kim D,D.N.H. Sparrow,H.L Nie, Howard Hu, and J.Schwartz, Childhood and Adult Socioeconomic Position, Cumulative Lead Levels, and Pessimism in Later Life, American Journal of Epidemiology, 174-12, 1345-1353,2011 